Gut, 1981, 22, 658-662

\title{
Loperamide: studies on its mechanism of action
}

\author{
B K S A N D H U, J H T R I P, D C A CANDY, A N J T HARRIES \\ From the Institute of Child Health and The Hospital for Sick Children, Great Ormond Street, London
}

SUMMARY The effects of loperamide on net solute and water absorption, and prostaglandin $\mathrm{E}_{2}$ $\left(\mathrm{PGE}_{2}\right)$ and cholera toxin-induced secretion were studied in the rat jejunum using an in vivo steady-state perfusion technique. Loperamide stimulated absorption of fluid, electrolytes, and glucose and reversed $\mathrm{PGE}_{2}$ and cholera toxin-induced secretion to absorption; this opiate analogue had no effect on cholera toxin stimulation of adenylate cyclase activity or the rise of tissue cyclic AMP (cAMP) concentrations. The opiate antagonist, naloxone, reduced the antisecretory effects of loperamide without affecting tissue levels of cAMP. These results indicate that loperamide inhibits $\mathrm{PGE}_{2}$ and cholera toxin-induced secretion, and that this phenomenon is independent of any direct effect that cholera toxin has on the adenylate cyclase system. The action of naloxone suggests, but does not prove, that loperamide exerts its effect via opiate receptors.

Loperamide, an opiate analogue, is a widely used anti-diarrhoeal agent and, until recently, its effects were attributed to an inhibitory action on smooth muscle tone and peristalsis mediated via both cholinergic and non-cholinergic systems. ${ }^{1-3}$ Karim and Adaikan, ${ }^{4}$ however, observed that loperamide modified prostaglandin $\mathrm{E}_{2}\left(\mathrm{PGE}_{2}\right)$ induced secretion of fluid in the rat intestinal tract and they postulated that its anti-diarrhoeal action might be related not only to an effect on intestinal motility, but also on secretory processes.

We have recently been impressed by the beneficial effects of very large oral doses of loperamide (up to $4 \mathrm{mg} / \mathrm{kg}$ body weight) in some but not all infants with severe and life-threatening protracted diarrhoea (unpublished observations). On the basis of these clinical observations we suspected that the effects of the drug could not be explained solely on its action on smooth muscle, and that it was inhibiting small intestinal secretion of fluid and electrolytes. This prompted us to study the effects of loperamide, and its possible mechanism of action, on two well-established secretagogues, $\mathrm{PGE}_{2}$ and cholera toxin, using a steady state perfusion technique in the rat jejunum in vivo.

The results of loperamide on cholera toxininduced secretion have been briefly reported in a letter. $^{5}$

*Address for correspondence: Dr J T Harries, Department of Child Health, 30 Guilford Street, London WC1N 1EH.

Received for publication 17 February 1981

\section{Methods}

PER F U S I O N S

All experiments were performed on male Wistar rats weighing $220-280 \mathrm{~g}$ after an overnight fast, during which water was allowed ad libitum; the designs of the experiments are shown in the Figure. Two hours before laparotomy the animals received intragastric loperamide $(4 \mathrm{mg} / \mathrm{kg}$ body weight) dissolved in $1 \mathrm{ml} 5 \%(\mathrm{v} / \mathrm{v})$ ethanol and water with omission of loperamide in controls. Anaesthesia was induced with intraperitoneal pentobarbitone $(6 \mathrm{mg} / \mathrm{kg})$, and maintained as necessary with intramuscular doses of $0.3 \mathrm{mg}$. The rectal temperature was maintained throughout the experiments at $37^{\circ} \mathrm{C}$ by overhead electric lamps. In the PGE $_{22}$ experiments the perfusions were essentially as described by Sladen and Harries." The abdomen was opened with a midline incision and $15-20 \mathrm{~cm}$ lengths of proximal jejunum (from the duodenojejunal junction) were prepared. An inlet catheter (vinyl tubing, bore $0.63 \mathrm{~mm}$, diameter $1.4 \mathrm{~mm}$, short hardness -70 , portex) was inserted into the gut lumen through a $2 \mathrm{~mm}$ incision in the antimesenteric border of the gut and tied firmly in place with a circumferential ligature. Faecal material, if present, was removed from the loops by washing with isotonic saline at $37^{\circ} \mathrm{C}$. A wider bore outlet catheter (bore $2 \mathrm{~mm}$, diameter $3 \mathrm{~mm}$, short hardness -70 , portex) was similarly inserted into the distal end of the loop for the continuous collection of effluent and the 
1.

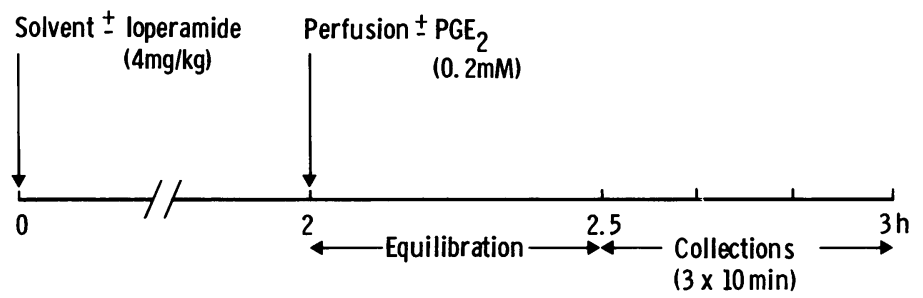

2.

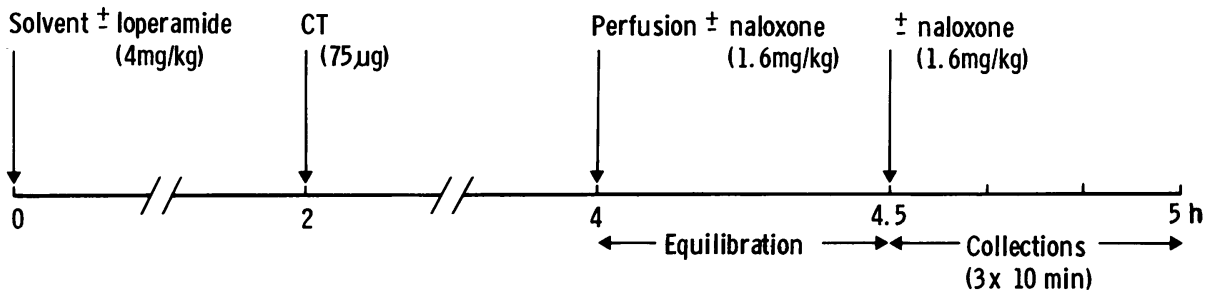

Figure Experimental design: (1) effect of loperamide on absorption, and on prostaglandin $E_{2}$ $\left(P G E_{2}\right)$ induced secretion; (2) effect of loperamide on cholera toxin $(C T)$ induced secretion and of naloxone in this system.

loop was returned to the abdominal cavity. The solutions were infused continuously at $0.46 \mathrm{ml} /$ min (Harvard 975 syringe pump), and were warmed by passage through the inlet catheter in a water bath at $37^{\circ} \mathrm{C}$. After an equilibration period of 30 minutes, three consecutive 10 minute collections of effluent were obtained. The perfusate contained (mmol/l) $\mathrm{NaCl}(130), \mathrm{KCl}(4)$, glucose (2), $\mathrm{NaHCO}_{3}(25)$, and polyethylene glycol $4000(3 \mathrm{~g} / \mathrm{l})$ with $5 \mu \mathrm{Ci} / 1$ of ${ }^{14} \mathrm{C}$ polyethylene glycol; $\mathrm{PGE}_{2}$ was added to the basic perfusate in a concentration of $0.2 \mathrm{mmol} / 1$, the $\mathrm{pH}$ was adjusted to 7.0 with $\mathrm{CO}_{2}$ and the osmolality of the solution was $290 \mathrm{mosmol} / \mathrm{kg}$.

A low $(2 \mathrm{mmol} / \mathrm{l})$ concentration of glucose was chosen, as luminal disappearance will reflect active transport and/or mucosal metabolism, and thus tissue viability. In all the experiments the concentration of glucose in the effluent ranged from 1.3 to $1.6 \mathrm{mmol} / \mathrm{l}$. The dose of $\mathrm{PGE}_{2}$ was that which consistently induced secretion of water, as established in preliminary experiments. The mean percentage recovery of ${ }^{14} \mathrm{C}$ polyethylene glycol for all the perfusions was 100 (range 95-105). At the end of the three 10-minute collection periods the animal was killed by cardiac puncture.

In the cholera toxin experiments a blind loop was initially constructed from the proximal 15$20 \mathrm{~cm}$ of jejunum as described by Harries and Sladen, ${ }^{7}$ and cholera toxin $(75 \mu \mathrm{g}$ dissolved in $0.75 \mathrm{ml}$ perfusate) was instilled into the loop, which was returned to the peritoneal cavity for two hours. The loop was then rinsed with perfusate and prepared for perfusion as in the $\mathrm{PGE}_{2}$ experiments; the composition of the perfusate was identical with the basic perfusate used in the $\mathrm{PGE}_{2}$ experiments. A second series of experiments with cholera toxin were carried out to study the effects of naloxone on the observed effects of loperamide on cholera toxin-induced secretion: naloxone was administered subcutaneously in two divided doses of $1.6 \mathrm{mg} / \mathrm{kg}$ at 4 and 4.5 hours as shown in the Figure. As with $\mathrm{PGE}_{2}$ the dose of naloxone was chosen on the basis of preliminary experiments, and the timing of its subcutaneous injection was based on studies in rats showing a half life of 30 to 40 minutes. $^{89}$ As all the animals were in a steady-state with respect to net water, electrolyte, and glucose absorption throughout the perfusion times, it was assumed that any effect of prolonged anaesthesia on absorption would be similar in control and test animals, and, therefore, comparisons are valid. In some experiments freeze-clamped, full-thickness biopsies of the perfused loops were obtained and stored at $-70^{\circ} \mathrm{C}$ for cyclic AMP (cAMP) assay. In other experiments mucosal scrapings were snap-frozen and stored at $-70^{\circ} \mathrm{C}$ for adenylate cyclase assay.

\section{A N A L Y S E S}

The initial solutions and effluent were analysed for sodium and potassium by flame photometry 
(Corning-E EL), chloride by coulometric titration (Corning-E EL), and glucose by hexokinaseG6PDH method (BCL, Lewes, UK); $500 \mu \mathrm{l}$ aliquots in duplicate were counted in Rialuma scintillant (LKB Instruments Ltd, Croydon, UK) for ${ }^{14} \mathrm{C}$ in an LKB (Wallac) scintillation counter. Loperamide was supplied by Janssen Pharmaceutical Ltd, Marlow, Buckinghamshire, $\mathrm{PGE}_{2}$ obtained from Upjohn Ltd, Crawley, Sussex, and CT Batch VT 2210 supplied by Wellcome Research Laboratories, Beckenham, Kent.

Adenylate cyclase activity was measured as described by Tripp et al. ${ }^{10}$ with the following modifications: the media were preincubated at $37^{\circ} \mathrm{C}$ for five minutes, $100 \mu \mathrm{l}$ of mucosal homogenate was incubated in $500 \mu \mathrm{l}$ of medium, the basal activity assay being incubated for 10 minutes and the fluoride stimulated assay for five minutes.

cAMP was assayed using a kit (Radiochemical Centre, Amersham, Buckinghamshire) by homogenising the freeze-clamped biopsies in $0.5 \mathrm{ml}$ EDTA ( $4 \mathrm{mM})$ buffer at $4^{\circ} \mathrm{C}$ and measuring cAMP by protein binding assay after precipitating homogenate protein by boiling. Protein concentration of the homogenate was measured using a Coomassie blue dye binding method. ${ }^{11}$

C A L C U L A T I O N S

Using ${ }^{14} \mathrm{C}$ polyethylene glycol as a non-absorbable marker absorption rates of fluid and solute were calculated from standard formulae, ${ }^{12}$ and in each rat a mean value was obtained from the three 10-minute collection periods. The significance of the difference between mean values was assessed by the unpaired Student's $t$ test.

\section{Results}

EFFECT OF LOPERA M I D ON

A B S OR P T ION A N D ON PGE ${ }_{2}$ IN D UCED

S E C R E T I O N (Table 1)

Pre-treatment with loperamide itself enhanced absorption of water $(P<0.05)$, sodium $(P<0.05)$, chloride $(\mathrm{P}<0.005)$, and glucose $(\mathrm{P}<0.05) . \mathrm{PGE}_{2}$ induced secretion of water $(P<0.001)$, sodium $(\mathrm{P}<0.001)$, potassium $(\mathrm{P}<0.001)$, and chloride

Table 1 Effect of loperamide on absorption and on $P G E_{2}$ induced secretion

\begin{tabular}{|c|c|c|c|c|c|}
\hline & \multicolumn{5}{|c|}{ Net absorption rates (units/min/g wet weight of gut) } \\
\hline & $\begin{array}{l}\text { Water } \\
(\mu l)\end{array}$ & $\begin{array}{l}\text { Sodium } \\
(\mu \mathrm{mol})\end{array}$ & $\begin{array}{l}\text { Potassium } \\
(\mu \mathrm{mol})\end{array}$ & $\begin{array}{l}\text { Chloride } \\
\text { ( } \mu \mathrm{mol})\end{array}$ & 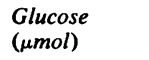 \\
\hline Controls (8) & $\begin{array}{l}+28.3 \pm 2.3 \\
\mathrm{P}<0.05\end{array}$ & $\begin{array}{l}+4.4 \\
<0.05\end{array} \pm 0.3$ & $\begin{array}{l}+0.06 \pm 0.01 \\
\text { NS }\end{array}$ & $\begin{array}{l}+1.9 \pm 0.9 \\
<0.005\end{array}$ & $\begin{array}{l}+0.03 \pm 0.02 \\
P<0.05\end{array}$ \\
\hline $\begin{array}{l}\text { Loperamide-treated (8) } \\
\text { PGE }_{2} \text { perfusion (8) } \\
\text { Loperamide-treated }+\mathrm{PGE}_{2} \text { perfusion (8) }\end{array}$ & $\begin{array}{l}+40 \cdot 1 \pm 4 \cdot 7 \\
-7 \cdot 3 \pm 1 \cdot 1 \\
P<0 \cdot 001 \\
+7 \cdot 4 \pm 2 \cdot 4\end{array}$ & $\begin{array}{l}+6 \cdot 3 \pm 0.8 \\
-1 \cdot 15 \pm 0.29 \\
P<0.001 \\
+1 \cdot 16 \pm 0.4\end{array}$ & $\begin{array}{l}+0.08 \pm 0.02 \\
-0.11 \pm 0.02 \\
P<0.01 \\
-0.02 \pm 0.02\end{array}$ & $\begin{array}{l}+5.3 \pm 0.02 \\
-1.37 \pm 0.62 \\
P<0.02 \\
+0.71 \pm 0.5\end{array}$ & $\begin{array}{l}+0.40 \pm 0.04 \\
+0.18 \pm 0.01 \\
\text { NS } \\
+0.23 \pm 0.02\end{array}$ \\
\hline
\end{tabular}

+Net absorption; - net secretion; values are given as mean \pm SEM.

Figures in parentheses denote number of animals in each group. NS: not significant.

$P$ values refer to values immediately above and below.

Table 2 Effects of cholera toxin (CT), loperamide, and naloxone on water absorption, tissue adenylate cyclase activity and cyclic AMP levels

\begin{tabular}{|c|c|c|c|c|}
\hline \multirow[b]{3}{*}{ Controls } & \multirow[t]{2}{*}{$\begin{array}{l}\text { Water absorption } \\
(\mu \mathrm{l} / \mathrm{min} / \mathrm{g} / \text { wet } / \text { weight })\end{array}$} & \multicolumn{2}{|c|}{$\begin{array}{l}\text { Adenylate cyclase } \\
(\text { pmollmg protein/min })\end{array}$} & \multirow[t]{2}{*}{$\begin{array}{l}\text { Cyclic AMP } \\
\text { (pmol/mg protein) }\end{array}$} \\
\hline & & Basal & Fluoride-stimulated & \\
\hline & $\begin{array}{l}+27.9 \pm 3.0 \\
P<0.001\end{array}$ & $\begin{array}{l}4.56 \pm 0.77 \\
P<0.05\end{array}$ & $\begin{array}{l}20 \cdot 3 \pm 1 \cdot 9 \\
\mathrm{NS}\end{array}$ & $\begin{array}{l}3 \cdot 06 \pm 0 \cdot 13 \\
P<0.001\end{array}$ \\
\hline CT treated & $\begin{array}{l}-24.0 \pm 2.3 \\
\mathrm{P}<0.001\end{array}$ & $\begin{array}{l}8.58 \pm 2.03 \\
\text { NS }\end{array}$ & $\begin{array}{l}15 \cdot 16 \pm 2 \cdot 21 \\
\text { NS }\end{array}$ & $\begin{array}{l}6.09 \pm 0.29 \\
\text { NS }\end{array}$ \\
\hline Loperamide + CT treated & $\begin{array}{l}+12.3 \pm 3.5 \\
P<0.005\end{array}$ & $9 \cdot 84 \pm 1 \cdot 77$ & $16 \cdot 97 \pm 2 \cdot 37$ & $\begin{array}{l}6 \cdot 01 \pm 0.38 \\
\text { NS }\end{array}$ \\
\hline Loperamide $+\mathrm{CT}+$ naloxone treated & $\begin{array}{l}-11 \cdot 7 \pm 5 \cdot 3 \\
\mathrm{NS}\end{array}$ & & & $\begin{array}{l}5 \cdot 80 \pm 0 \cdot 18 \\
\text { NS }\end{array}$ \\
\hline $\mathrm{CT}+$ naloxone treated & $-17 \cdot 5 \pm 3 \cdot 4$ & & & $5 \cdot 57 \pm 0 \cdot 2$ \\
\hline
\end{tabular}

+ Net absorption; - net secretion; values are given as mean \pm SEM.

Figures in parentheses denote the number of animals in each group; NS: not significant.

$P$ values refer to values immediately above and below. 
$(P<0.005)$ and inhibited glucose absorption $(\mathrm{P}<0.001)$. Pre-treatment with loperamide reversed secretion of water $(P<0.001)$, sodium $(P<0.001)$, and chloride $(\mathrm{P}<0.02)$ to absorption, though rates of absorption did not return to normal control values; secretion of potassium was reduced $(\mathbf{P}<0.01)$. Glucose absorption was enhanced but the values were not statistically different from the $\mathrm{PGE}_{2}$ group not given loperamide.

EF F E C T O F C T, LOP ER A M D E A N NALOXONE ON WATER A BSORPTION, T IS S U E D E NYLATE CYCLASE

A C T I V I T Y, A N D C A M P LE V E L S (Table 2) Cholera toxin induced secretion of water $(P<0.001)$, and increased basal adenylate cyclase activity $(\mathrm{P}<0.05)$ without affecting fluoridestimulated activity; cholera toxin had a similar effect on tissue CAMP levels $(P<0.001)$. Loperamide reversed secretion of water to absorption $(P<0.001)$ but had no effect on adenylate cyclase activity or CAMP levels. Naloxone reduced the antisecretory effects of loperamide $(P<0.005)$, absorption of water reverting to secretion without any effect on tissue cAMP.

\section{Discussion}

This study clearly demonstrates that in large doses loperamide markedly inhibits small intestinal secretion induced by cholera toxin and $\mathrm{PGE}_{2}$, and supports our clinical observations that the effects of the drug in patients with severe protracted diarrhoea may in part be due to its antisecretory properties. This is in keeping with our findings that the small intestine is in a secretory state in such children. ${ }^{13}$

Previous studies have shown a close temporal relationship between tissue cAMP concentrations, adenylate cyclase activity and the onset of secretion after exposure of the small intestine to cholera toxin, as well as to other agents which increase tissue cAMP, suggesting that the secretory process is intimately linked to the cAMP system. ${ }^{14-16}$ Prostaglandin-induced secretion closely mimics that produced by cholera toxin in terms of tissue cAMP changes and electrical phenomena $^{14}{ }^{17}$; there are differences, however, in the secretion $^{14}$ suggesting that the two secretagogues act via different or additional mechanisms.

In the present experiments loperamide inhibited cholera toxin induced secretion without any effect on the increased activity of adenylate cyclase or the tissue concentrations of cAMP. Moreover, naloxone which reduced the anti-secretory effects of loperamide also had no effect on tissue cAMP levels. These observations suggest that loperamide acts at a point distal to the increase in tissue cAMP. in modifying the secretory process. The finding that $\mathrm{PGE}_{2}$ inhibited glucose absorption is in agreement with previous reports, ${ }^{18}{ }^{19}$ and is in marked contrast to the lack of any effect of cholera toxin on glucose absorption, which is also in agreement with both our ${ }^{5}$ and other previous studies. ${ }^{18}{ }^{21}$ In addition, loperamide itself enhanced absorption of water, electrolytes, and glucose from an isotonic buffer containing glucose, and partially reversed the effects of $\mathrm{PGE}_{2}$ on water and electrolytes transport.

Although this study has not defined the precise mechanism(s) by which loperamide modifies cholera toxin and $\mathrm{PGE}_{2}$ induced secretion, the results suggest that the effects of the opiate analogue do not result from a direct effect on the cyclic AMP system. The data indicate that the antisecretory actions of loperamide occur via a naloxone sensitive mechanism, and as naloxone is an opiate antagonist, this in turn suggests that the effects of loperamide may be mediated by opiate receptors. However, only one concentration of the agonist and antagonist was investigated in the present study and additional studies directed towards demonstrating a dose-related effect of antagonist and agonist activity would add support to the notion that opiate receptors are involved.

BKS thanks Janssen Pharmaceuticals Ltd for financial support. DCAC acknowledges the financial support of the Rayne Foundation. The authors would like to thank Dr R O Thompson, Wellcome Research Laboratories, Beckenham, UK, for generously providing the cholera toxin.

\section{References}

${ }^{1}$ Van Nueten JM, Janssen PAJ, Fontaine J. Loperamide (R18553); a novel type of antidiarrhoeal agent. III. In vitro studies in the peristaltic reflex and other experiments on isolated tissues. Arzneim Forsch 1974; 24:1641-5.

${ }^{2}$ Niemberger CJE, Lenaerts FS, Janssen PAJ. Loperamide (R18553), a novel type of antidiarrhoeal agent. I. In vitro oral pharmacology and acute toxicity; comparison with morphine, codeine, diphenoxylate and difenoximine. Arzneim Forsch 1974; 24:1633-6.

${ }^{3}$ Nakayama S, Yamasato T, Mizutani M. Effects of loperamide on the motility of the isolated intestine in guinea pigs, rats and dogs. Japan J Smooth Muscle Res (Sendai) 1977; 13:69-74.

${ }^{4}$ Karim SMM, Adaikan PG. The effect of loper- 
amide on prostaglandin induced diarrhoea in rat and man. Prostaglandins 1977; 13:321-31.

'Sandhu Bhupinder, Tripp JH, Candy DCA, Harries JT. Loperamide inhibits cholera toxin-induced small intestinal secretion. Lancet 1979; 2:689-90.

'Sladen GE, Harries JT. Studies on the effects of unconjugated dihydroxy bile salts on rat small intestinal function in vivo. Biochim Biophys Acta 1972; 288:443-56.

${ }^{7}$ Harries JT, Sladen GE. The effects of different bile acids on the absorption of fluid, electrolytes, and monosaccharides in the small intestine of the rat in vivo. Gut 1972; 13:596-603.

${ }^{8}$ Berkowitz BA, Ngaj SH, Sempstead J. Spector S. Disposition of naloxone: use of a new radioimmunoassay. J Pharmacol Exp Ther 1975; 195:499-504.

${ }^{N}$ gai SH, Berkowitz BA, Yang JC, Hempstead J, Spector S. Pharmacokinetics of naloxone in rats and in man: basis for its potency and short duration of action. Anesthesiology 1976; 44:398-401.

${ }^{10}$ Tripp JH, Muller DPR, Harries JT. Mucosal ( $\mathrm{Na}^{+}$ $\left.-\mathrm{K}^{+}\right)$-ATPhase and adenylate cyclase activities in children with toddler diarrhoea and the post-enteritis syndrome. Pediatr Res 1980; 14:1382-6.

${ }^{11}$ Bradford MM. A rapid and sensitive method for quantitation of microgram quantities of protein utilising the principles of protein-dye binding. Anal -Biochem 1976; 72:248-54.

12 Sladen GE, Dawson AM. Interrelationships between the absorptions of glucose sodium and water by the normal human jejunum. Clin Sci 1969; 36:119-32.

${ }^{13}$ Candy DCA, Larcher VF, Tripp JH, Milla P, Pincott J, Norman AP, Harries JT. Lethal familial protracted diarrhoea of infancy. Arch Dis Childh 1981; 56:15-23.

${ }^{14}$ Kimberg DV, Field M, Johnson J, Henderson A, Gershon E. Stimulation of intestinal mucosal adenyl cyclase by cholera enterotoxin and prostaglandins. J Clin Invest 1971; 50:1218-30.

${ }^{15}$ Field M, Kimberg DV, Gershon E, Henderson A. Effects of prostaglandins and cholera enterotoxin on intestinal mucosal cyclic AMP accumulation. J Clin Invest 1974; 53:941-9.

${ }^{16}$ Guerrant RL, Chen LC, Sharp GWG. Intestinal adenyl-cyclase activity in canine cholera: correlation with fluid accumulation. J Infect Dis 1972; 125:37781.

${ }^{17}$ Mathias JR, Carlson GM, Bertiger G, Martin J, Cohen S. Migrating action potential complex of cholera: a possible prostaglandin-induced response. Am J Physiol 1977; 232:E529-E534.

${ }^{18}$ Coupar M, McColl I. Inhibition of glucose absorption by prostaglandins $E_{1}, E_{2}$ and $F_{2} . J$ Pharmacol 1972; 24:254-5.

${ }^{19}$ Matuchansky C, Bernier J. Effect of prostaglandin $E_{1}$ on glucose, water and electrolyte absorption in the human jejunum. Gastroenterology 1973; 64: 1111-8.

20Pierce NF, Carpenter CCJ, Elliott HL, Greenough WB. III. Effects of prostaglandins, theophylline, and cholera exotoxin upon transmucosal.water and electrolyte movement in the canine jejunum. Gastroenterology 1971; 60:22-32.

${ }^{21}$ Carpenter GCJ. Cholera enterotoxin-recent investigations yield insights into transport processes. $\mathrm{Am}$ J Med 1971; 50:1-6. 